\title{
A NOTE ON THE EFFECT OF METRONIDAZOLE ON THE NICHOLS STRAIN OF TREPONEMA PALLIDUM IN VITRO AND IN VIVO* \\ BY
}

\author{
A. E. WILKINSON AND P. RODIN \\ Whitechapel Clinic, The London Hospital, \\ AND \\ J. A. MCFADZEAN AND S. SQUIRES \\ Research Laboratories, May and Baker Ltd
}

In addition to its effect on Trichomonas vaginalis, metronidazole has also been found to be active against the organisms causing Vincent's gingivitis. This has raised the question of its possible action on Treponema pallidum, although Scott-Gray and Murrell (1961) found that a short course of $1.8 \mathrm{~g}$. given over 48 hours did not affect a case of primary syphilis, and Yobs, Clark, and Schroeter (1966) found that large doses did not affect the course of syphilis in rabbits infected with the Nichols strain of Trepomena pallidum. Davies (1967), however, has reported that doses of 2 to $4 \mathrm{~g}$. daily caused the disappearance of Treponema pallidum from the lesions of six patients with secondary syphilis with subsequent healing of the lesions; smaller doses were without effect. Davies, McFadzean, and Squires (1964) have reported that the minimum inhibitory concentration of metronidazole for the cultivable Reiter treponeme is $0.02 \mu \mathrm{g} . / \mathrm{ml}$. These observations prompted the examination of the effect of serum containing metronidazole on the Nichols strain of Treponema pallidum in vitro.

\section{Methods}

Specimens of blood were taken from twenty female patients with trichomoniasis before treatment was started with a dosage of $200 \mathrm{mg}$. three times daily for 7 days and again towards the end of the course when they reattended for observation. Sixteen of the women were white and four coloured; none showed any clinical evidence of syphilis and all were sero-negative on routine testing with the Reiter protein complement-fixation test, cardiolipin Wassermann reaction, and Price's precipitation reaction. The sera were separated and stored at $-20^{\circ} \mathrm{C}$. until tested. They were examined without inactivation, serial dilutions of $0.25 \mathrm{ml}$. being made in a pool of TPI-negative serum and an equal volume of a suspension of Treponema pallidum (Nichols strain) containing ten to fifteen organisms per field in $T$. pallidum immobilization medium added. A similar

* Received for publication May 24, 1967. mixture of treponemes plus pre-treatment serum acted as a control. The mixtures were incubated anaerobically at $35^{\circ} \mathrm{C}$. for 18 hours and the percentage of motile treponemes was estimated. The difference between the test and control readings was expressed as a percentage of the motility in the control tube for each serum. Similar tests were also performed in which known amounts of metronidazole were added to a pool of TPI-negative serum and the concentration of the drug producing 50 per cent. immobilization estimated. The concentration of metronidazole in the pre- and post-treatment sera was also estimated by a polarographic method (Kane, 1961).

\section{Results}

The results of the in vitro tests and polarographic estimations are summarized in the Table (overleaf).

The concentration of metronidazole producing 50 per cent. immobilization of treponemes was found to be $3 \cdot 6,3 \cdot 6,4 \cdot 1$, and $9 \cdot 5 \mu \mathrm{g} . / \mathrm{ml}$. in four experiments (mean $5 \cdot 2 \mu \mathrm{g} . / \mathrm{ml}$.). The results of the in vitro tests on the patients' sera showed only fair agreement with the polarographic estimations, but undiluted serum from eight of the patients immobilized 50 per cent. or more of the treponemes and in six of these sera the metronidazole content of the sera was $5 \mu \mathrm{g} . / \mathrm{ml}$. or more by polarography. No metronidazole was found in any of the pre-treatment sera. A review of the patients' records showed that serological tests for syphilis were negative in twelve at periods of 6 weeks to 9 months after treatment; eight patients ceased to attend before this investigation was carried out. No clinical evidence of syphilis was found, but one patient, who was pregnant, was found to be a contact of a patient with primary syphilis 6 weeks after treatment with metronidazole. She was sero-negative and showed no clinical evidence of infection, but was treated with penicillin as a precautionary measure.

To assess the effect of metronidazole on early syphilis in the dosage currently used for treating trichomoniasis, a 30-year-old Somali seaman with a darkfield-positive chancre of the prepuce was 
TABLE

PERCENTAGE IMMOBILIZATION OF TREPONEMES BY SERA AND THEIR METRONIDAZOLE CONTENT

\begin{tabular}{|c|c|c|c|c|c|c|c|}
\hline \multirow{2}{*}{ Case No. } & \multirow{2}{*}{ Day of Treatment } & \multicolumn{5}{|c|}{ Per cent. Immobilization at Serum Dilutions* } & \multirow{2}{*}{$\underset{(\mu \mathrm{g} . / \mathrm{ml} .) \dagger}{\text { Serum }}+\underset{ }{\text { Metronidazole }}$} \\
\hline & & Neat & $1 / 2$ & $1 / 4$ & $1 / 8$ & $1 / 16$ & \\
\hline $\begin{array}{l}\text { W11725 } \\
\text { W10275 } \\
\text { W6835 } \\
\text { W10837 } \\
\text { W11575 } \\
\text { W11513 } \\
\text { W11051 } \\
\text { W } 11607 \\
\text { W11611 } \\
\text { W11573 } \\
\text { W11677 } \\
\text { W11691 } \\
\text { W11015 } \\
\text { W9595 } \\
\text { W11091 } \\
\text { W11639 } \\
\text { W11803 } \\
\text { W11803 } \\
\text { W1 } 10683 \\
\text { W11821 } \\
\text { W11999 }\end{array}$ & $\begin{array}{l}-6 \\
6 \\
6 \\
6 \\
7 \\
6 \\
5 \\
6 \\
7 \\
6 \\
6 \\
6 \\
7 \\
6 \\
6 \\
6 \\
5 \\
7 \\
4 \\
6 \\
6\end{array}$ & $\begin{array}{r}23 \\
0 \\
39 \\
62 \\
0 \\
80 \\
78 \\
11 \\
92 \\
48 \\
16 \\
63 \\
36 \\
38 \\
63 \\
0 \\
0 \\
17 \\
73 \\
33\end{array}$ & $\begin{array}{r}8 \\
0 \\
62 \\
0 \\
37 \\
0 \\
74 \\
65 \\
0 \\
24 \\
4 \\
12 \\
46 \\
12 \\
0 \\
74 \\
0 \\
0 \\
0 \\
0 \\
9\end{array}$ & $\begin{array}{r}4 \\
67 \\
0 \\
0 \\
51 \\
9 \\
0 \\
0 \\
0 \\
0 \\
0 \\
4 \\
0 \\
26\end{array}$ & $\begin{array}{r}0 \\
13 \\
0 \\
15 \\
0 \\
\\
0 \\
0\end{array}$ & 5 & $\begin{array}{c}1.0 \\
0 \\
20.5 \\
6 \cdot 8 \\
8 \cdot 0 \\
2 \cdot 2 \\
3.6 \\
5.0 \\
2.0 \\
0.7 \\
8 \cdot 0 \\
3.8 \\
5.0 \\
3.8 \\
3.2 \\
1.9 \\
4.6 \\
9.7 \\
3.6\end{array}$ \\
\hline
\end{tabular}

* These represent initial dilutions of serum, the final dilutions are twice this because of the addition of treponeme suspension.

† Polarographic estimations.

treated as an in-patient with $200 \mathrm{mg}$. metronidazole thrice daily for 7 days.

Daily darkfield examinations for $T$. pallidum were performed; actively motile treponemes were seen on each occasion although they were more difficult to find on the fifth and sixth days of treatment. On the seventh day the lesion appeared unchanged and darkfield examination showed one to four actively motile $T$. pallida per $\frac{1}{12}$ " field. The patient was then treated with 2.4 mega units benzathine penicillin.

Specimens of serum were obtained before and on the third, fifth, and seventh days of the metronidazole course. The metronidazole content was estimated polarographically and the treponemicidal effect was tested by mixing equal volumes of the inactivated serum and a suspension of $T$. pallidum (Nichols strain) in TPI medium and determining the percentage of motile treponemes after 18 hours incubation at $35^{\circ} \mathrm{C}$. under anaerobic conditions. The results were as follows:

\begin{tabular}{c|c|c}
\hline & $\begin{array}{c}\text { Metronidazole Concentration } \\
\mu \mathrm{g} . / \mathrm{ml} .\end{array}$ & Per cent. Motility \\
\hline 0 & 0 & 98 \\
3 & $11 \cdot 1$ & 58 \\
5 & $12 \cdot 1$ & 72 \\
7 & $9 \cdot 2$ & 68 \\
\hline
\end{tabular}

Allowing for the added treponeme suspension, the sera were tested at a dilution of 1 in 2 . Some immobilization of trepomenes was evident while the patient was receiving metronidazole but as stated above this was not associated with healing and actively motile treponemes persisted in the lesion throughout treatment.

\section{Discussion}

In assessing the possible effect of therapeutic doses of metronidazole for trichomoniasis on
Treponema pallidum, both the serum concentration and the time for which it is maintained need to be considered. In the experimental model, a concentration of $5.2 \mu \mathrm{g} . / \mathrm{ml}$. maintained for 18 hours immobilized 50 per cent. of treponemes. It is not known whether immobilization under these conditions means that the organisms are killed, as happens in the TPI test. Rodin, King, Nicol, and Barrow (1960) found serum levels of $2 \cdot 7$ to $13 \mu \mathrm{g}$./ $\mathrm{ml}$. between the third and seventh days of treatment in nine patients given $200 \mathrm{mg}$. metronidazole three times daily for 7 days. Seven of these patients had serum levels of $5 \mu \mathrm{g} . / \mathrm{ml}$. or more. Figures published by Kane, McFadzean, Squires, King, and Nicol (1961) on the serum levels attained in twelve patients after a single dose of $200 \mathrm{mg}$. showed mean levels attained of 4.8 and $4.5 \mu \mathrm{g} . / \mathrm{ml}$. after 1 and 2 hours respectively, falling to $0.8 \mu \mathrm{g} . / \mathrm{ml}$. after 24 hours. Estimations on the serum of a single patient who was given three doses of $200 \mathrm{mg}$. at 4-hourly intervals showed concentrations of $4 \cdot 6$ to $7 \cdot 4 \mu \mathrm{g}$. $/ \mathrm{ml}$. between 4 and 9 hours after the initial dose and of $3.6 \mathrm{\mu g} . / \mathrm{ml}$. after 24 hours. From these results it seems possible that patients receiving this standard dosage over a week for the treatment of trichomoniases may develop concentrations of the drug which can affect Treponema pallidum. These may be reached only intermittently, and it seems unlikely that with this low dosage a concomitant syphilitic infection would be masked or aborted.

Sera from patients under treatment with metronidazole should not be submitted for TPI tests as the presence of the drug may invalidate the test through poor survival of treponemes. 


\section{Summary}

(1) Sera from patients under treatment for trichomoniasis with metronidazole may immobilize T. pallidum (Nichols strain) in vitro.

(2) Treatment of a patient with darkfield-positive primary syphilis with $200 \mathrm{mg}$. metronidazole three times daily for 7 days did not heal the lesion and $T$. pallida were still demonstrable in it at the end of the course.

(3) Although it is possible, it seems unlikely that the usual dosage of metronidazole for trichomoniasis (200 mg. three times daily for 7 days) will mask a concomitant infection with syphilis.

\section{REFERENCES}

Davies, A. H. (1967). Brit. F. vener. Dis., 43, 197. , McFadzean, J. A., and Squires, A. (1964). Brit. med. $\mathcal{F} ., 1,1149$.

Kane, P. O. (1961). F. polarograph. Soc., 7, 58. McFadzean, J. A., Squires, S., King, A. J., and Nicol, C. S. (1961). Brit. F. vener. Dis., 37, 273.

Rodin, P., King, A. J., Nicol, C. S., and Barrow, J. (1960). Ibid., 36, 147.
Scott-Gray, M., and Murrell, M. (1961). Practitioner, 186, 218.

Yobs, A. R., Clark, J. W., and Schroeter, A. L. (1966). Brit. F. vener. Dis., 42, 122.

Quelques notes sur l'effet de la métronidazole sur le treponema pallidum (souches de Nichols) in vitro et in vivo

\section{RÉSUMÉ}

(1) Le sérum des patients traités pour la trichomoniase avec de la métronidazole peut immobiliser le $T$. pallidum (souche de Nichols) in vitro.

(2) La lésion syphilitique primaire d'un malade prouvée positive sur fond noir n'avait pas guéri avec $200 \mathrm{mg}$. de métronidazole donnés trois fois par jour pendant sept jours et les $T$. pallida pouvaient être montrés dans cette lésion à la fin du traitement.

(3) Il semble improbable que la dose usuelle de métronidazole employée pour le traitement de la trichomoniase $(200 \mathrm{mg}$. trois fois par jour pendant 7 jours) masquerait une infection concomitante de la syphilis, mais cette possibilité demeure. 